\title{
Creating a nationwide cancer registration system to support AIDS-cancer match studies in Nigeria
}

\author{
Clement Adebamowo*, Elima Jedy-Agba, Emmanuel Oga, Peju Osinubi, Festus Igbinoba, Gloria Osubor, \\ Theresa Otu, Henry Kumai, Michael Okobia, Prince Ejiroghene, Ahmed Mayun, James Abdulazeez, O Erinomo, \\ Adebayo Ojo, Cornelius Uka, Gloria Oyeoka
}

From 13th International Conference on Malignancies in AIDS and Other Acquired Immunodeficiencies (ICMAOI)

Bethesda, MD, USA. 7-8 November 2011

\section{Background}

Cancer registration started in Nigeria in 1962 but after a very promising start, the momentum was lost $[1,2]$. Since 2009, Nigerian Health Ministry, IARC and IPRI, have given training, troubleshooting and mentoring.

\section{Material and methods}

20 cancer registries were trained and 5 have met criteria for population based cancer registries. Data for 2009 are presented in this report.

\section{Results}

The commonest cancer at all sites is Prostate in men and Breast in women. There was a gradient in the incidence that paralleled the socio-economic development of the regions of the country. The ASR for breast cancer ranged from 101.1 in Abuja to 7.5 in less cosmopolitan areas. For Prostate the ASR ranged from 73 in Abuja to 1.7. The other common cancers were Kaposi Sarcoma and Colo-Rectal in men, and cervix in women. Additional data collection and analysis is ongoing.

\section{Conclusions}

This study showed that breast and cervical cancer are the commonest in women while prostate is the commonest cancer in men.

Published: 19 April 2012
References

1. Parkin DM, Ferlay J, Hamdi-Cherif M, Sitas F, Thomas JO, Wabinga H, Whelan SL: Cancer in Africa: Epidemiology and Prevention. Lyon: IARC Press; 2003.

2. Solanke TF, Adebamowo AC: Report of the Workshop on the State of the Art in Oncology in Ibadan and Ife. Ibadan: National Headquarters of Cancer Registries in Nigeria; 1998.

doi:10.1186/1750-9378-7-S1-P3

Cite this article as: Adebamowo et al:: Creating a nationwide cancer registration system to support AIDS-cancer match studies in Nigeria. Infectious Agents and Cancer 2012 7(Suppl 1):P3.
Submit your next manuscript to BioMed Central and take full advantage of:

- Convenient online submission

- Thorough peer review

- No space constraints or color figure charges

- Immediate publication on acceptance

- Inclusion in PubMed, CAS, Scopus and Google Scholar

- Research which is freely available for redistribution
C Biomed Central

\footnotetext{
* Correspondence: cadebamo@yahoo.com
}

Nigerian National Cancer Registry System

(c) 2012 Adebamowo et al; licensee BioMed Central Ltd. This is an open access article distributed under the terms of the Creative 